\title{
BRISELES IBIS REGULAS PIEMĒROŠANA LATVIJAS TIESĀS
}

\section{APPLICATION OF THE BRUSSELS IBIS REGULATION BY LATVIAN COURTS}

\author{
Aleksandrs Fillers, Dr. iur., LL.M
}

Rīgas Juridiskās augstskolas docents

\section{Summary}

In a cross-border dispute, court's first task is to determine jurisdiction. In the European Union, courts most frequently do it on the basis of the Brussels Ibis Regulation. The objective of this article is to demonstrate some of the complexities that Latvian courts have faced when applying the said regulation. The author focuses on two specific examples from the Latvian court practice. They demonstrate two types of errors made by Latvian courts. On the one hand, some of the errors made by Latvian courts could have been avoided in future at the national level. The author hopes that this contribution will help courts in future with this task. On the other hand, some of the complexities cannot be resolved locally. They arise from the (overly) complex nature of some of the provisions of the Brussels Ibis Regulation. However, in such cases, Latvian courts should consider requesting a preliminary ruling from the Court of Justice of the European Union. Unfortunately, the two cases discussed in this article show that courts are not that keen on doing that.

Atslēgvārdi: Briseles Ibis regula, īpašā jurisdikcija, izṇēmuma jurisdikcija

Keywords: Brussels Ibis Regulation, special jurisdiction, exclusive jurisdiction

\section{Ievads}

Šì raksta mērḳis ir kritiski izvērtēt divus nolēmumus no Latvijas tiesu prakses, kuros ir piemērota Briseles Ibis regula: 2016. gada 12. oktobra Rïgas apgabaltiesas lēmumu lietā Nr. C30486115 un 2019. gada 21. marta Augstākās tiesas rīcības sēdes lēmumu lietā Nr. SKC-193/2019. ${ }^{2}$ Rìgas apgabaltiesa savā lēmumā interpretēja Briseles Ibis regulas normas par izṇēmuma jurisdikciju, bet Augstākā tiesa - normas par izņēmuma un īpašo jurisdikciju. Autora skatījumā abas lietas vieno divi apstākḷi: 1) tiesām bija pamats uzdot prejudiciālo jautājumu Eiropas Savienības Tiesai (turpmāk - EST), jo tām bija jālemj par objektīvi neviennozīmīgiem Eiropas Savienības (turpmāk - ES) privāttiesību

\footnotetext{
1 Rīgas apgabaltiesas 12.10.2016. lēmums lietā Nr. C30486115. Nav publicēts.

2 Augstākās tiesas 21.03.2019. rīcības sēdes lēmums lietā Nr. SKC-193/2019. Pieejams: http://www.at. gov.lv/downloadlawfile/5754 [aplūkots 10.03.2020.].
} 
jautājumiem; 2) tiesas piel̦āva tādas interpretācijas kḷūdas, kuras nākotnē būtu vēlams novērst arī bez vēršanās pie EST.

\section{Rìgas apgabaltiesas lēmums lietā Nr. C30486115}

Rìgas apgabaltiesas lēmums ir interesants tādā ziṇā, ka tajā ir piemērots Briseles Ibis regulas 24. panta 2. punkts, ko tiesas piemēro salīdzinoši reti. Briseles Ibis regulas 24. panta 2. punkts paredz, ka izñēmuma jurisdikcija ir: "lietā, kuras priekšmets ir uzņēmējsabiedrību, citu juridisko personu vai fizisku vai juridisku personu apvienību izveides spēkā esamība, to darbības izbeigšana vai likvidācija, vai to pārvaldes struktūru pieņemto lēmumu spēkā esamība, - tās dalībvalsts tiesām, kurā ir uzṇēmējsabiedrības, juridiskās personas vai apvienības atrašanās vieta. Lai noteiktu šo atrašanās vietu, tiesa piemēro starptautisko privāttiesību normas [..]”.

Konkrētajā lietā pastāvēja strīds starp Latvijā reǵistrētu komercsabiedrību (prasītāja) un Amerikas Savienotajās Valstīs reǵistrētu komercsabiedrību (atbildētāja). Prasītāja lūdza tiesai atzīt, ka starp pusēm bijis noslēgts sabiedrības līgums, ar kuru tika izveidota civiltiesiska sabiedrība (personu apvienība) Civillikuma 2241. panta izpratnē, lai iegādātos kādas Latvijas bankas akcijas. Pirmās instances tiesa uzskatīja, ka tās jurisdikciju nevar pamatot ar Briseles Ibis regulas 24. panta 2. punktu, jo prasītājas prasība bija celta par civiltiesiska līguma atzǐšanu par spēkā esošu, un tāda prasība neietilpa minētās normas tvērumā. Šì iemesla dēl pirmās instances tiesa pieñēma lēmumu izbeigt tiesvedību. Par šo lēmumu prasītāja iesniedza blakus sūdzību. To izskatot, apgabaltiesa secināja, ka prasības priekšmets aptvēra arī prasījumu atzīt, ka "ar šo sabiedrības līgumu prasīājs un atbildētājs izveidojuši personas apvienību [..]”. ${ }^{3} \mathrm{Li} d z$ ar to apgabaltiesas ieskatā Briseles Ibis regulas 24. panta 2. punkts bija piemērojams. Taču apgabaltiesas argumentācijā var identificēt divu veidu trūkumus: 1) tiesa neievēroja Briseles Ibis regulas interpretācijas metodoloǵijas pamatprincipus, un 2) tiesas lēmums demonstrē arī nepietiekamu izpratni par regulas 24. panta 2. punkta piemērošanas īpatnībām.

Pie pirmās kategorijas var pieskatìt divas apgabaltiesas paustās atziñas. Pirmkārt, apgabaltiesa pārmeta pirmās instances tiesai, ka tā, interpretējot Briseles Ibis regulu, izmantojusi EST sniegto Briseles I regulas interpretāciju. Šāds secinājums ir pretrunā ar Briseles Ibis regulas preambulas 34. apsvērumu, kurā ir tieši norādìts, ka EST prakse, kas attiecas uz Briseles konvenciju un Briseles I regulu, ir piemērojama arī Briseles Ibis regulas interpretācijai. Izṇēmums no šì principa būtu piel̦aujams tikai tad, ja regulas autori būtu apzināti atkāpušies no iepriekšèjās konvencijas vai regulas teksta. ${ }^{4}$

Otrkārt, apgabaltiesa savu kritiku pamatoja arī ar to, ka Briseles Ibis regulas 24. panta 2. punkts atšķiroties no analoǵiskā Briseles I regulas 22. panta 2. punkta. Patiešām, starp abu pantu formulējumiem latviešu valodā pastāv stilistiskas

3 Rīgas apgabaltiesas 12.10.2016. lēmums lietā Nr. C30486115. Nav publicēts.

4 Dickinson A., Lein E., James A. (eds.). The Brussels I Regulation Recast. Oxford: Oxford University Press, 2015, p. 27, para. 1.71; Magnus U., Mankowski P. (eds.). European Commentaries on Private International Law. Vol. I. Brussels Ibis Regulation. Köln: Otto Schmidt, 2016, p. 38. 
atškirīibas. ${ }^{5}$ Tomēr apgabaltiesas lēmumā nav izskaidrots, kādā veidā šādas stilistiskas atšķirības regulu tekstos varēja ietekmēt jurisdikcijas noteikšanu. Taču vēl būtiskāks apstāklis ir tas, ka minēto normu teksts atšḳiras tieši latviešu valodā; citās valodās analoǵiskā norma nav mainījusies. Doktrīnā tiek atzìts, ka principā ES tiesību piemērotājam būtu jāiepazīstas ar tiesību normas tekstu visās oficiālajās ES valodās. ${ }^{6}$ Šāda pieeja diez vai ir praktiski realizējama. Tomēr tiesai vajadzēja izmantot vismaz vienu alternatīvu versiju (citā ES oficiālā valodā), pirms nākt pie secinājuma, ka starp abām regulām pastāv būtiska atškirirība.

Taču apgabaltiesas argumentācijā ir arī tādi trūkumi, kas saistīti tieši ar Briseles Ibis regulas 24. panta 2. punkta izpratni. Un tas nav pārsteidzoši, jo minētā norma ir objektīvi neskaidra un sarežg̀ita. Pirmkārt, pats normas tvērums nav acīmredzams. Tiesību doktrīnā tiek norādìts, ka Briseles Ibis regulas 24. panta 2. punkts varētu tikt piemērots arī tādām sabiedrībām, kurām nav juridiskās personas statusa. ${ }^{7}$ Taču šìs atziṇas piemērošana praksē nav acīmredzama. Kā jau minēts iepriekš, tad pirmās instances tiesa uzskatīja, ka prasības priekšmets bija sabiedrības līguma atzī̌ana par noslēgtu. Tādējādi šāda prasība vispār neietilpa izṇēmuma jurisdikcijas tvērumā. Tomēr apgabaltiesas ieskatā šāda prasība neizbēgami lika izvērtēt arī civiltiesiskas sabiedrības (personu apvienības) esamību. Autora skatījumā, lai atrisinātu šo viedokḷu pretrunu, apgabaltiesai bija pamats uzdot prejudiciālo jautājumu EST. EST atbilde varētu sniegt būtisku pienesumu jautājumā par regulas 24. panta 2. punkta tvērumu, kas ir objektīvi neviennozìmīgs attiecībā uz tādām personu apvienībām, kurām nav juridiskās personas statusa.

Taču regulas 24. panta 2. punkta tvēruma noteikšana nebija vienīgā grūtība, ar kuru nācās saskarties apgabaltiesai. Arī minētās normas piesaiste ir neskaidra. Apgabaltiesa nepareizi secināja, ka sabiedrības atrašanās vietu varēja noteikt, atsaucoties uz regulas 63. pantu. Patiešām, regulas 63. pants ir izmantojams, lai noteiktu uzṇēmējsabiedrības vai citas juridiskās personas, vai fizisku un juridisku personu apvienības domicilu; taču tas nav piemērojams tieši tajā gadījumā, kad jurisdikciju nosaka saskaṇā ar regulas 24. panta 2. punktu.

Šādu secinājumu pamato šādi apsvērumi. Briseles Ibis regulas 24. panta 2. punktā ir tieši norādìts, ka tajā uzskaitīto subjektu "atrašanās vietu" nosaka saskaṇā ar starptautisko privāttiesību normām. Proti, ar to ir domāts, ka tiesai ir jāpiemēro savas nacionālās kolīziju normas, lai noteiktu šo "atrašanās vietu". Šāds risinājums ir saglabājies no Briseles konvencijas. ${ }^{8}$ Tā mērḳis bija nodrošināt sakritību starp jurisdikciju un piemērojamo likumu juridiskām personām, un Briseles konvencijas autori vēlējās, lai tieši kolīziju norma kalpotu vienlaikus arī

5 Briseles I regulas 22. panta 2. punkts bija formulēts (latviešu valodā): “šādām tiesām ir izṇēmuma jurisdikcija neatkarīgi no domicila tiesvedībā, kuras priekšmets ir uzṇēmējsabiedrību, citu juridisku personu vai fizisku vai juridisku personu apvienību struktūras spēkā esamība [..]”. Savukārt Briseles Ibis regulas 24. panta 2. punkts ir formulēts (latviešu valodā): "šādām dalībvalsts tiesām ir izṇēmuma jurisdikcija neatkarīgi no pušu domicila lietā, kuras priekšmets ir uzṇēmējsabiedrību, citu juridisko personu vai fizisku vai juridisku personu apvienību izveides spēkā esamība [...”.

6 Dickinson A., Lein E., James A. 2015, pp. 17-18, para. 1.49; Magnus U., Mankowski P. 2016, p. 43.

Magnus U., Mankowski P. 2016, p. 572.

Sk.: ibid., p. 561. 
par jurisdikcijas normu. ${ }^{9}$ Šo mērḳi nevarēja panākt, unificējot jurisdikcijas normas, jo Briseles konvencijas sākotnējās dalībvalstis izmantoja divu veidu kolizziju normas juridiskām personām. Nīderlande izmantoja "reg̣istrācijas/inkorporācijas teoriju", ${ }^{10}$ kas paredzēja, ka juridiskai personai piemēro tās valsts likumu, kurā juridiskā persona ir reǵistrēta. ${ }^{11}$ Pārējās dalībvalstis izmantoja "patiesā sēdekḷa teoriju". ${ }^{12}$ Saskaṇā ar to juridiskām personām piemērojamo likumu noteica pēc to faktiskās pārvaldes vietas. ${ }^{13}$ Briseles konvencijai bija jānodrošina, ka tādas valsts tiesai, kurā izmanto "reǵistrācijas teoriju", būtu izņēmuma jurisdikcija, ja juridiskā persona būtu reǵistrēta attiecīgajā dalībvalstī. Savukārt tādas valsts tiesai, kura izmanto "patiesā sēdekḷa teoriju", būtu izṇēmuma jurisdikcija, ja juridiskās personas patiesais sēdeklis atrastos attiecīgajā dalībvalstī.

Tātad, nosakot jurisdikciju saskaņā ar Briseles Ibis regulas 24. panta 2. punktu, apgabaltiesa nevarēja atsaukties uz regulas 63. pantu. Taču kā gan Latvijas tiesai būtu jāpiemēro regulas 24. panta 2. punkts? Atbildēt uz šo jautājumu ir sarežğìti divu iemeslu dẹḷ: 1) Latvijas kolīziju normu specifikas dẹḷ; 2) objektīvu neskaidrību dēḷ par Briseles Ibis regulas 24. panta 2. punkta piemērošanu tādām sabiedrībām, kurām nav juridiskās personas statusa.

Latvijas "vietējā specifika" ir saistīta ar neskaidro "patiesā sēdekḷa teorijas" statusu Latvijas kolīziju tiesībās. Civillikuma 8. panta trešajā dạ̦ā ir noteikts, ka juridiskas personas tiesību un rīcības spēja nosakāma pēc viņas valdes atrašanās vietas likuma. Tomēr, lai arī "[..] Civillikuma 8. pants formāli seko patiesā sēdekḷa teorijai, praksē patiesā sēdekḷa teorija nekad nav bijusi izmantota [..]. De facto valda "reg̣istrācijas vietas" teorija [..]". ${ }^{14}$ Šādā situācijā pašām Latvijas tiesām būtu jānāk pie secinājuma, kāda kolīziju norma īsti darbojas Latvijā, jo tas atvieglotu arī izṇēmuma jurisdikcijas noteikšanu saskaṇā ar Briseles Ibis regulas 24. panta 2. punktu.

Taču ir arī cits jautājums: ja Latvijas tiesas dotu priekšroku "registrācijas vietas" teorijai, vai to varētu piemērot, lai noteiktu izņēmuma jurisdikciju strīdā par tādas sabiedrības esamību, kurai principā nav nedz juridiskās personas statusa, nedz reǵistrācijas. Apskatāmajā lietā strīds bija saistīts tieši ar tādas sabiedrības atzī̌šnu. Vai šādā gadỉjumā dalībvalstīm nebūtu citas iespējas, kā vien piemērot patiesā sēdekḷa teoriju? ${ }^{15}$ Un arī tās piemērošana ir sarežğita: kur atrastos valde, ja runa ir par tādu personu apvienību, kurai nav šādas institūcijas, bet tās dalībnieki atrodas dažādās valstīs un nav iespējams konstatēt konkrētu vietu, kurā tiktu pieņemti lēmumi par sabiedrības līguma izpildi?

${ }^{9}$ Sk.: Convention on jurisdiction and the recognition and enforcement of judgments in civil and commercial matters, signed in Lugano on 30 October 2007 - Explanatory report by Professor Fausto Pocar, para. 96-97. Pieejams: https://eur-lex.europa.eu/legal-content/HR/TXT/?uri=CELEX:52009XG1223(04) [aplūkots 10.03.2020.]; Magnus U., Mankowski P. 2016, p. 571.

${ }^{10}$ Kieninger E.-M. The Legal Framework of Regulatory Competition Based on Company Mobility: EU and US Compared. German Law Journal, 2005, pp. 759-760.

11 Behrens P. Centros and the Proper Law of Companies. In: Ferrarini G., Hopt K. J., Wymeersch E. (eds.). Capital Markets in the Age of the Euro. Cross-Border Transactions, Listed Companies and Regulation. The Hague: Kluwer Law International, 2002, p. 505.

12 Kieninger E.-M. 2005, pp. 759-760.

13 Ibid., p. 744

14 Precinieks G. Eiropas Savienības dalībvalstī reg̣istrētai sabiedrībai piemērojamais likums: vai atvadas no kolīzijtiesiskā regulējuma? Grām.: Tiesību integrācija un jaunrade - kā rast pareizo līdzsvaru. Latvijas Universitātes 71. zinātniskās konferences rakstu krājums. Rīga: LU Akadēmiskais apgāds, 2013, 195.-196. lpp.

15 Vismaz tekstuāli Civillikuma 8. panta trešā daḷa būtu attiecināma tikai uz juridiskām personām. 
Autora skatījumā atbildes uz šiem jautājumiem ir nesaraujami saistītas ar jau minēto jautājumu par regulas 24. panta 2. punkta tvērumu. Lai saṇemtu atbildi uz visu šo jautājumu kopumu, Rīgas apgabaltiesai vajadzēja uzdot prejudiciālo jautājumu EST, lūdzot paskaidrot, vai Briseles Ibis regulas 24. panta 2. punkts vispār ir piemērojams strīdā par civiltiesiska sabiedrības līguma spēkā esamību un kā tehniski būtu piemērojama tā piesaiste. EST atbilde l̦autu labāk izprast Briseles Ibis regulas 24. panta 2. punkta piemērojamības iespējas un tā piemērošanas tehniku šādos gadījumos.

\section{Augstākās tiesas rīcības sēdes lēmums lietā Nr. SKC-193/2019}

Arī Augstākās tiesas rīcības sēdes lēmums norāda uz zināmiem trūkumiem Latvijas tiesu praksē attiecībā uz Briseles Ibis regulas piemērošanu. Lēmumā ir sniegtas atziṇas par Briseles Ibis regulas 24. panta 4. punkta un 7. panta pirmās daļas a) punkta piemērošanu. Regulas 24. panta 4. punkts paredz, ka lietā attiecībā uz tādu patentu, preču zīmju, dizainparaugu vai citu līdzīgu tiesību registrāciju vai spēkā esamību, kas jādeponē vai jāreǵistrē, - tās dalībvalsts tiesām ir izṇēmuma jurisdikcija, kurā deponēšana vai reǵistrācija ir pieteikta vai veikta vai kurā to uzskata par veiktu saskaṇā ar kāda ES instrumenta vai starptautiskas konvencijas noteikumiem. Savukārt saskaṇā ar regulas 7. panta pirmās daḷas a) punktu īpašā jurisdikcija lietās, kas attiecas uz līgumiem, ir attiecīgās saistības izpildes vietas tiesai.

Konkrētajā lietā Latvijā registrēta komercsabiedrība (prasītāja) bija iesniegusi prasību, lūdzot atzìt par spēkā neesošu līgumu par preču zìmes atsavināšanu, kas ticis noslēgts starp Jaunzēlandes sabiedrību - preču zìmes atsavinātāju - un kādu personu ar domicilu Spānijā (atbildētāja). Pēc prasītājas domām, Jaunzēlandes sabiedrībai, kas bija izslēgta no Jaunzēlandes komercsabiedrību reǵistra, nebija nepieciešamās tiesībspējas un rīcībspējas, lai noslēgtu šādu līgumu.

Rīcības sēdes lēmumā Augstākā tiesa secināja: lai arī zemākās instances tiesas nepamatoti nebija izvērtējušas starptautiskās jurisdikcijas esamību saskaṇā ar Briseles Ibis regulas normām, tomēr tiesu kḷūdas nebija novedušas pie nepareizas pārrobežu jurisdikcijas noteikšanas. Pamatojot šo secinājumu, Augstākā tiesa pareizi norādīja, ka šajā gadījumā nebija piemērojams Briseles Ibis regulas 24. panta 4. punkts, jo tas esot attiecināms tikai uz prasībām par pašu reǵistrējamo intelektuālā īpašuma tiesību reǵistrāciju vai spēkā esamību, bet konkrētajā lietā prasības priekšmets bija līguma atzīšana par spēkā neesošu. ${ }^{16}$

Tomēr Augstākās tiesas ieskatā tas nenozīmēja, ka Latvijas tiesām nebija jurisdikcijas izskatīt konkrēto strīdu. Tieši pretēji - Augstākā tiesa norādīja, ka saskaņā ar Briseles Ibis regulas 7. panta pirmās daḷas a) punktu jurisdikcija bija Latvijas tiesām, jo līguma izpilde bija veicama, pārreǵistrējot preču zīmi Latvijas Republikas Patentu valdē. Tātad arī preču zìmes atsavināšanas līguma izpildes vieta bija Latvijā.

Doktrīnā ir izteikts viedoklis, ka "lieta attiecas uz līgumiem" arī tad, ja prasību ceḷ trešā persona, kas nav lìguma dalībnieks, lūdzot atzìt lìgumu par spēkā

\footnotetext{
16 Augstākā tiesa pamatoti atsaucās uz EST 16.11.2016. spriedumu lietā C-417/15 Wolfgang Schmidt pret Christiane Schmidt. Šajā lietā EST noteica, ka prasības priekšmets nav lietu tiesības saistībā ar nekustamo īpašumu, ja prasība ir celta par dāvinājuma akta atzišanu par spēkā neesošu dāvinātāja rīcỉbspējas trūkuma dēḷ. Šàda prasība neietilpst Briseles Ibis regulas 24. panta 1. punkta tvērumā.
} 
neesošu. ${ }^{17}$ Tomēr būtu interesanti uzzināt arī Augstākās tiesas viedokli šajā jautājumā. Diemžēl lēmumā nav izvērtēts, vai attiecīgā Briseles Ibis regulas norma vispār ir piemērojama gadījumā, kad prasību ceḷ persona, kura nav līguma puse. Tà kā jautājums nav viennozīmīgs, iespējams, arī to vajadzētu risināt ar prejudiciāla jautājuma palīdzību.

Rìcības sēdes lēmumā ir arī otrs trūkums. Proti, saskañā ar Briseles Ibis regulas 7. panta pirmās daḷas a) punktu jurisdikcija nosakāma pēc attiecīgās saistības izpildes vietas. Minētā norma neparedz iespēju visu līgumu pakḷaut vienam forumam. Piemērojot minēto normu, jurisdikcija ir jānosaka konkrētai saistībai, nevis visam līgumam. ${ }^{18}$ Tas pēc būtības padara apgrūtinātu minètās normas piemērošanu prasībām, ar kurām tiek prasīts atzīt līgumu par spēkā neesošu. Tiesību doktrīnā ir sniegti vairāki piedāvājumi, kā risināt šādu situāciju, taču piemērotākais risinājums nav acīmredzams. ${ }^{19}$ Principā Augstākajai tiesai būtu bijis jāuzdod jautājums EST, jo no šì jautājumu risinājuma bija atkarīgs arī secinājums, vai lieta varēja tikt izskatīta Latvijā.

Taču šì raksta kontekstā autors vēlētos vērst uzmanību arī uz daudz vienkāršāku jautājumu, kuru pareizi atrisināt Augstākā tiesa varēja arī bez EST iesaistīšanas. No Augstākās tiesas rīcības lēmuma skaidri izriet: ja reiz Latvijas tiesām ir starptautiskā jurisdikcija, tad nacionālo jurisdikciju (piekritību) nosaka nacionālās tiesību normas. Šāds secinājums atbilst arī Latvijas tiesību doktrīnā izteiktajam viedoklim, ka "[..] Briseles Ibis regulas II nodaḷas mērķis ir noteikt piekritīgo valsts tiesu pārrobežu civilstrīdos un komercstrīdos [..]. Šìs regulas normas nav piemērojamas, lai noskaidrotu attiecīgās dalībvalsts piekritīgo tiesu". ${ }^{20}$ Šāds viedoklis nav pareizs. EST savā praksē ir norādījusi, ka īpašās jurisdikcijas pamati nosaka gan starptautisko, gan nacionālo jurisdikciju. ${ }^{21}$ Arī ārvalstu tiesību doktrīnā tiek norādīts, ka visi īpašās jurisdikcijas pamati, kas ietverti Briseles Ibis regulas 7. pantā (izņemot tā 6. punktu), nosaka arī nacionālo jurisdikciju. $^{22}$

Apkopojot iepriekšminēto, ir jāsecina, ka Augstākā tiesa palaida garām iespēju uzdot EST prejudiciālo jautājumu par Briseles Ibis regulas 7. panta pirmās daḷas a) punkta piemērojamību trešās personas prasībai atzīt līgumu par spēkā neesošu. Šādam prejudiciālam jautājumam varēja būt gan teorētiska, gan praktiska nozīme, kas padarītu skaidrāku regulas piemērošanu arī citās dalībvalstīs. Vienlaikus Augstākā tiesa savā lēmumā ir palaidusi garām iespēju paskaidrot zemākstāvošām tiesām, ka Briseles Ibis regulas 7. pants iekḷauj normas, kas nosaka arī nacionālo jurisdikciju, un tām ir prioritāte pār nacionālajos normatīvajos aktos ietvertajām piekritības normām.

17 Magnus U., Mankowski P. 2016, p. 173.

18 Ibid., pp. 245-246.

19 Piedāvāto risinājumu uzskaitījumu sk.: ibid., p. 249.

${ }^{20}$ Vingris M. Briseles Ibis regulas piemērojamības noskaidrošana un jurisdikcijas noteikšana Latvijas tiesu praksē. Jurista Vārds, 2019, Nr. 43.

21 EST ir norādijusi, ka "Regulas Nr. 44/2001 5. panta 1. punkta b) apakšpunkta pirmā ievilkuma, nosakot gan starptautisko jurisdikciju, gan teritoriālo jurisdikciju, mērķis ir [..] tieši noteikt kompetento tiesu, neatsaucoties uz dalíbvalstu iekšējiem noteikumiem”. EST 03.05.2007. spriedums lietā C386/05 Color Drack GmbH pret Lexx International Vertriebs $\mathrm{GmbH}$, 30. rindkopa.

22 Magnus U., Mankowski P. 2016, pp. 144-145. Tas atbilst arī Briseles konvencijas autoru izpratnei. Sk.: Report on the Convention on jurisdiction and the enforcement of judgments in civil and commercial matters by P. Jenard, p. 22. Pieejams: http://aei.pitt.edu/1465/1/commercial_report_jenard_C59_79.pdf [aplūkots 10.03.2020.]. 


\section{Kopsavilkums}

1. Komentētajās lietās tiesām bija objektīvi sarežğìts uzdevums - mēgeināt piemērot tādas Briseles Ibis regulas normas, par kuru pareizu izpratni turpinās strīdi visā Eiropā. Šajā kontekstā tiesām bija rūpīgi jāapsver iespēja uzdot prejudiciālo jautājumu. EST atbilde būtu noderīga ne tikai konkrētajās lietās, bet arī uzlabotu Briseles Ibis regulas izpratni citās dalībvalstīs.

2. Vienlaikus abās lietās tiesas bija piệāvušas arī tādas kḷūdas, kuras tās pašas varēja novērst. İpaši tas attiecas uz Augstāko tiesu, kurai būtu bijis jāprecizē, ka Briseles Ibis regula tomēr var noteikt arī nacionālo jurisdikciju.

3. Tomēr tiesas diez vai ir pelnijušas pārlieku skarbu kritiku. Daudzās ES dalībvalstīs nacionālās tiesas, piemērojot ES starptautisko privāttiesību normas, var izmantot bagātīgu akadēmisko materiālu, kas acīmredzami atvieglo normu piemērošanu. Latvijā ES starptautisko privāttiesību normas ir salīdzinošai vāji skaidrotas akadēmiskā līmenī. Bez šādas akadēmiskās bāzes nav pārsteigums, ka tiesām ne vienmēr veicas ar šo normu piemērošanu. 